\title{
Implikasi Putusan Mahkamah Konstitusi Terhadap Komisi Yudisial Dalam Pengawasan Etik Hakim : Studi Kasus Putusan Mahkamah Konstitusi 005/PUU-IV/2006
}

\author{
Muhammad Hasan Basri \\ Magister Hukum Fakultas Hukum Universitas Islam Indonesia Yogyakarta Indonesia \\ Jln. Cik Di Tiro No. 1 Yogyakarta Indonesia \\ muhammadhasanbasri1515@gmail.com
}

\begin{abstract}
The study discusses the implications of the Constitutional Court's Number 005/PUU-IV/2006 decision on material review of the judicial commission in the supervision of judges' ethics. The research method used is normative juridical with case and statutory approaches. The results of this study conclude that: first, the Decision of the Constitutional Court Number 005/PUU-IV/2006 which states that the articles of supervision of the Judicial Commission are contrary to the 1945 Constitution and have no binding legal force, have weakened the authority of the Judicial Commission in external supervision of the judiciary in Indonesia. Second, the decision of the Constitutional Court which states that the judges of the Constitutional Court are not supervised by the Judicial Commission, are actually incorrect because constitutional judges are also judges whose behavior needs to be monitored by external supervisory institutions so that there is no disparity in supervision by the Judicial Commission against perpetrators of judicial power. Third, there is an urgency for one-roof supervision by the Judicial Commission on judicial power, both judges at the Supreme Court and the Constitutional Court as well as judges under the Supreme Court.
\end{abstract}

Key Words: Constitutional Court Decision; Judicial Commission

\begin{abstract}
Abstrak
Penelitian membahas implikasi putusan Mahkamah Konstitusi Nomor 005/PUU-IV/2006 atas pengujian materiil terhadap komisi yudisial dalam pengawasan etik hakim. Metode penelitian yang digunakan bersifat yuridis normatif dengan pendekatan kasus dan perundang-undangan. Hasil penelitian ini menyimpulkan bahwa: pertama, Putusan Mahkamah Konstitusi Nomor 005/PUU-IV/2006 yang menyatakan bahwa pasal-pasal pengawasan Komisi Yudisial bertentangan dengan UUD 1945 dan tidak mempunyai kekuatan hukum mengikat telah memperlemah kewenangan Komisi Yudisial dalam pengawasan secara eksternal lembaga kekuasaan kehakiman di Indonesia. Kedua, Putusan Mahkamah Konstitusi yang menyatakan bahwa hakim Mahkamah Konstitusi tidak termasuk yang diawasi oleh Komisi Yudisial, sesungguhnya tidak tepat karena hakim konstitusi juga hakim yang perlu diawasi perilakunya oleh lembaga pengawas eksternal supaya tidak terjadi disparitas pengawasan oleh Komisi Yudisial terhadap pelaku kekuasaan kehakiman. Ketiga, adanya urgensi untuk pengawasan satu atap oleh Komisi Yudisial terhadap kekuasaan kehakiman baik itu hakim di Mahkamah Agung dan Mahkamah Konstitusi serta hakim-hakim yang berada dibawah MA.
\end{abstract}

Kata-kata Kunci: Putusan Mahkamah Konstitusi; Komisi Yudisial 


\section{Pendahuluan}

Perubahan Undang-Undang Dasar yang dilakukan pada (1999-2002) sangat berpengaruh pada perubahan ketatanegaraan di Indonesia, Salah satu materi dari perubahan tersebut adalah pelembagaan organ untuk menunjang kekuasaan kehakiman menjadi pilihan yang ditempuh oleh para perumus perubahan UUD NRI 1945.

Hal ini kemudian mendorong lahirnya pelembagaan Komisi Yudisial (KY) dalam UUD NRI 1945. Mengenai sistem pengangkatan hakim, dalam masa perubahan tahap kedua UUD NRI 1945, 8 Juni 2000, I Dewa Gede Palguna mengusulkan pembentukan suatu badan yang mandiri, yaitu KY pada tingkat nasional maupun daerah yang bertugas mengusulkan pengangkatan hakim. Palguna menyatakan;

"Untuk menghindari intervensi kekuasaan eksekutif terhadap para hakim, kami mengusulkan pembentukan suatu badan yang mandiri yang kami sebut Komisi Yudisial (KY) pada tingkat nasional maupun daerah, sehingga kalau dahulu hakim agung diangkat oleh Presiden dan hakim-hakim diangkat oleh Menteri kehakiman, sekarang kami mengusulkan untuk hakim agung diangkat oleh Presiden, berdasarkan usul KY nasional, dan untuk hakim biasa maksudnya diluar hakim agung, diangkat oleh Presiden berdasarkan KY di daerah. ${ }^{1}$

Ali Masykur Musa dari Fraksi PKB juga menyatakan bahwa "hendaknya KY nasional atau komnas, bertugas dalam hal pengangkatan, kemudian promo pengangkatan, serta mutase hakim-hakim agung."2 Dalam masa perubahan ketiga UUD NRI 1945. Risalah rapat pleno ke 35 PAH I BP MPR, Selasa 25 September 2001 ketika membahas Pasal 24b Ayat (1) UUD NRI 1945. Pataniari Siahan menyatakan;

"Di sini kami ingin mengusulkan bahwa dalam Bab IX seyogyanya ada masalah-masalah yang menyangkut MA ada menanagani masalah-masalah konstitusi bagaimana melakukan seleksi rekrutmen terhadap "hakim agung dan hakim-hakim". Kita sekarang sama-sama sepakat mutu hakim kita masih tetap menjadi pertanyaan dikalangan masyarakat. Mekanisme rekrutmen seyogyanya ditangani oleh suatu lembaga yang lebih layak dan tepat untuk mengatasi masalah tersebut". ${ }^{3}$

\section{Selanjutnya Harjono menyatakan;}

"Pada persoalan rekrutmen hakim. KY memang dalam ketentuan ini masih terbatas untuk menyeleksi calon-calon hakim agung. Satu pertanyaan kalau

${ }^{1}$ Lihat Naskah Komprehensif Buku (VI) Perubahan UUD 1945, Risalah Perubahan Kekuasaan Kehakiman, hlm. 611-612

2 Ibid., hlm. 621

3 Ibid., hlm. 645 
hakim agung sekarang itu sudah ada kemungkinan masuknya jalur non karir. Pertanyaan berikutnya kenapa itu pada hakim agung saja, pada hakim tinggi dan pada hakim tingkat pertama apa juga tidak dibuka mekanisme seperti itu, apa bedanya sebetulnya?. Menurut saya titik yang paling kritis sebenarnya bukan di MA, tapi sebetulnya pengadilan di tingkat I dan II. Oleh karena itu bicara tentang persoalan KY, barangkali mulai kita pikirkan apakah KY ini kita tidak gunakan untuk mengubah cara rekrutmen hakim."

Hal yang hampir sama juga disampaikan oleh Soewarno dari Fraksi PDIP yang menyatakan perlunya keterlibatan KY dalam menyeleksi hakim-hakim di bawah Mahkamah Agung. ${ }^{5}$

"kami sarankan tentang kewenangan KY bukan hanya hakim agung tapi seluruhnya meliputi hakim agung, hakim tinggi, hakim pengadilan negeri mereka semua adalah hakim yang tidak bisa tiap tahun dimintai pertanggungjawabannya oleh MPR. Oleh karena itu rekrutmen adalah suatu tempat yang paling krusial dalam menentukan kehandalan dari para hakim tersebut." 6

Perdebatan mengenai kewenangan KY dalam megusulkan pengangkatan calon hakim konstitusi bukanlah wacana kosong. Perdebatan ini juga hadir dalam masa perubahan ketiga UUD NRI 1945. I Ketut Astawa dari Fraksi TNI/Polri, mengusulkan agar hakim konstitusi diusulkan oleh KY atas persetujuan dari DPR dan diangkat atau dilantik secara seremonial oleh Presiden. ${ }^{7}$

Terkait dengan pengawasan hakim, Hamdan Zoelva dari Fraksi PBB, menyampaikan bahwa;

"Pengawasan atau kontrol tidak boleh diserahkan kepada lembaga tinggi maupun lembaga tinggi negara yang sarat muatan politik. Kami berpendapat bahwa untuk melakukan kontrol terhadap Mahkamah Agung termasuk terhadap para hakim-hakim khususnya berkaitan dengan pelaksanaan tugas yudisial, perlu dibentuk sebuah komisi independent yang anggotanya dipilih oleh DPR dan disahkan oleh Presiden selaku kepala negara dari para mantan hakim, mantan jaksa, pengacara-pengacara senior, maupun professor hukum dari universitas terkemuka ditambah tokoh masyarakat yang kesemuanya memiliki integritas yang sangat tinggi dan tanpa cacat moral sedikitpun. Komisi ini diberikan kewenangan untuk melakukan pemeriksaan terhadap hakim-hakim yang diduga melakukan penyimpangan termasuk keanehan dalam produk putusan hakim yang dihasilkan. Hasil pemeriksaan komisi ini dalam menentukan karir seorang hakim dan termasuk hukuman penurunan

\footnotetext{
${ }^{4}$ Ibid., hlm. 653.

5 Ibid., hlm. 655

${ }^{6}$ Ibid., hlm. 657

${ }^{7}$ Ibid., hlm. 536
} 
pangkat atau pemberhentian seandainya komisi merekomendasikannya. Halhal ini harus diatur dalam konstitusi". 8

Istilah pengawasan hakim ini mendapatkan resistensi yang cukup kuat dari beberapa golongan terutama datang dari Fraksi TNI/Polri. Istilah pengawasan terhadap hakim dikhawatirkan menggangu kemandirian hakim dalam memutus perkara. Meskipun dikesempatan yang sama I Gede Dewa Palguna menitikberatkan bahwa pengawasan yang dimaksud pada prinsipnya lebih kepada kehormatan dan perilaku hakimnya. ${ }^{9}$ Pada titik ini, istilah pengawasan diubah menjadi frasa dalam menjaga dan menegakan etika dan perilaku para hakim. ${ }^{10}$

Terkait lembaga siapa yang memegang kewenangan tersebut, perumus perubahan UUD NRI 1945 memilih Komisi Yudisial sebaga organ negara yang independen yang bertugas menegakkan kehormatan dan perilaku hakim. Meskipun arah perdebatan politik hukum sempat menginventaris beberapa persoalan yang akan timbul ketika memilih Komisi Yudisial sebagai organ yang bertugas menegakan judicial condunt para hakim. ${ }^{11}$

Paripurna MPR RI Ke-6, 8 November 2001 yang dipimpin oleh M. Amien Rais, telah mengukir sejarah baru dalam rumpun kekuasaan kehakiman, yang secara constitutionally based power memberikan Komisi Yudisial kewenangan dalam Pasal 24B UUD NRI 1945. Komisi Yudisial bersifat mandiri yang berwenang mengusulkan pengangkatan hakim agung, dan mempunyai wewenang lain dalam rangka menjaga dan menegakkan kehormatan, keluhuran martabat, serta perilaku hakim. ${ }^{12}$

Untuk menghindari tingginya resistensi terhadap organ negara ini, maka secara kelembagaan KY tidak didesain sebagai bagian dari kekuasaan pemerintah, melainkan didesain sebagai organ negara independen. Hal ini didasari adanya preseden buruk antara hubungan departemen kehakiman dengan lembaga peradilan di era Demokrasi Terpimpin dan Orde Baru.

Meskipun KY tidak mempunyai kuasa dalam fungsi yustisi, keberadaan Komisi Yudisial merupakan sebuah langkah besar dari para perumus perubahan konstitusi (second framer of constitution). Sebab tidak dapat dipungkiri KY hadir sebagai bagian dari semangat reformasi peradilan. Ikhwal pelembagaan KY di atas membawa dua konlusi besar dalam pembenahan tata kelola kehakiman.

\footnotetext{
${ }^{8}$ Ibid., hlm. 603-604

${ }^{9}$ Ibid., hlm. 351.

10 Ibid., hlm. 352-252.

${ }^{11}$ Idul Rishan, Kebijakan Reformasi Peradilan, Cetakan Pertama, FH UII PRESS, Yogyakarta, 2019, hlm. 153

12 Lihat Kewenangan KY dalam pasal 24B ayat (1) UUD NRI Tahun 1945.
} 
Pertama mengenai sistem pengangkatan hakim (judicial appointment) dan kedua, mengenai pentingnya pengawasan terhadap perilaku hakim (judicial conduct) ${ }^{13}$.

Terdapat empat faktor pendorong pembentukan KY dalam struktur ketatanegaraan RI. Pertama, akibat pergeseran konfigurasi politik rezim pemerintahan dari yang sifatnta otoritarian kemudian bergerak ke arah yang lebih demokratis. Kedua, akibat gejala reaksional atas praktik politisasi jabatan hakim yang kerap mendapatkan intervensi pemerintah. Ketiga, pengaruh trend atau globalisasi organ negara sejenis judicial council yang telah diadopsi oleh negara-negara Uni Eropa. Keempat, ketiadaan organ yang dapat menjadi penghubung antara aktor kekuasaan kehakiman dengan masyarakat untuk melakukan monitoring secara intensif terhadap proses penyelenggaraan kekuasaan kehakiman. ${ }^{14}$

Di awal pasca transisi, hubungan antara lembaga pengawas eksernal (KY) Komisi Yudisial dan pelaku lembaga kekuasaan kehakiman terbilang cukup sulit untuk membangun hubungan yang kolektif. Upaya menegakan kehormatan dan perilaku hakim cenderung mendapatkan resistensi yang cukup besar dari (MA) Mahkamah Agung dan (MK) Mahkamah Konstitusi. Persoalan akseptabilitas menjadi problem utama bekerjanya fungsi pengawasan guna menegakan kehormatan dan perilaku hakim. ${ }^{15}$

Di awal-awal kiprahnya Komisi Yudisial dihadapkan dengan persoalan konstitusionalitas. Para hakim agung menjadi cukup resisten sebagai subjek yang harus di awasi secara eksternal. Harapan untuk menegakan kehormatan dan perilaku hakim melalui peran KY mengalami stagnasi. Beberapa ajudikasi peradilan baik di MK justru melemahkan perannya sebagai lembaga eksernal. Putusan MK soal uji Materiil yang menjadi objek penulisan jurnal ini , Putusan MK dalam Uji Materiil turut memangkas kewenangan konstitusionalitas Komisi Yudisial dalam menegakan kehormatan, keluhuran martabat dan perilaku hakim. Tabel 1: Putusan MK Dalam Uji Materiil Terhadap Pelemahan Kewenangan KY

\begin{tabular}{|c|c|c|c|}
\hline Putusan & Tahun & $\begin{array}{c}\text { Model } \\
\text { Ajudikasi }\end{array}$ & Pelemahan Kewenangan \\
\hline $\begin{array}{l}\text { Putusan MK } \\
\text { Nomor 005/PUU-IV/2006. }\end{array}$ & 2006 & $\mathrm{MK}$ & $\begin{array}{l}\text { Pembatalan } \\
\text { pengawasan } \\
\text { konstitusi. }\end{array}$ \\
\hline
\end{tabular}

${ }^{13}$ Ibid., hlm. 156

${ }^{14}$ Idul Rishan, Karakteristik Independensi Peradilan Pasca Amandemen UUD 1945, Laporan Penelitian Litbang FH UGM, Yogyakarta, hlm. 32

${ }^{15}$ Jual Beli Perkara Adalah Adalah Salah Satu Bentuk Dari Mafia Peradilan. Dalam Skala Lebih Luas, Mafia Peradilan Adalah Jejaring Yang Berupaya Memperdagangkan Hukum Dan Keadilan. Semakin Tertutup Pengadilan, Mafia Peradilan Semakin Menemukan Puncak Kekuatannya. Lihat Saldi Isra, 2009, "Kekuasaan Dan Perilaku Korupsi”, Kompas, Jakarta, hlm. 161 
Mencermati Putusan MK di atas, setidaknya arah kemerdekaan kekuasaan kehakiman belum diikuti dengan semangat membangun organisasi kelembagaan yang akuntabel di tubuh peradilan. Denny Indrayana menilai putusan-putusan yang lahir melalui ajudikasi peradilan dalam konteks pengawasan hakim cenderung kompromistis. ${ }^{16}$ Sudah semestinya kemerdekaan kekuasaan kehakiman seharusnya diikuti dengan kelembagaan yang akuntabel. Salah satu tolak ukurannya ialah adanya fungsi pengawasan secara eksternal dari komisi negara independen layaknya Komisi Yudisial.

\section{Rumusan Masalah}

Berdasarkan uraian-uraian tersebut permasalahan pokok yang akan dikaji dalam penelitian ini sebagai berikut: pertama, bagaimanakah implikasi putusan MK atas Uji Materiil terhadap Komisi Yudisial dalam pengawasan etik hakim? Kedua, bagimanakah Urgensi Pengawasan kekuasaan kehakiman secara eksternal oleh Komisi Yudisial?

\section{Tujuan Penelitian}

Penelitian ini bertujuan: Pertama, untuk mengetahui implikasi putusan MK atas uji materiil terhadap Komisi Yudisial dalam pengawasan etik hakim. Kedua, Untuk mengetahui urgensi pengawasan kekuasaan kehakiman oleh Komisi Yudisial.

\section{Metode Penelitian}

Penelitian ini menggunakan metode penelitian normatif dengan pendekatan kasus, teori, dan perundang-undangan. Bahan hukum primer yang digunakan ialah UUD NRI 1945, peraturan perundang-undangan, dan putusan pengadilan, ${ }^{17}$ yang didukung pula dengan bahan hukum sekunder berupa buku-buku, jurnal, karya ilmiah, surat kabar. Bahan hukum tersebut diperoleh melalui studi dokumen dan studi kepustakaan, yang kemudian dianalisis secara kualitatif.

\section{Hasil Penelitian dan Pembahasan}

\section{Putusan MK Atas Uji Materiil terhadap Kewenangan Komisi Yudisial dalam Pengawasan Etik Hakim}

Putusan Mahkamah Konstitusi Nomor 005/PUU-IV/2006 yang menyatakan bahwa pasal-pasal pengawasan Komisi Yudisial bertentangan dengan UUD 1945

${ }^{16}$ Lihat Denny Indrayana, Negeri Para Mafioso: Hukum Di Sarang Koruptor, 2008, hlm. 56

17 Peter Mahmud Marzuki, Penelitian Hukum, Prenada Media, Jakarta, 2011, hlm. 181 
dan tidak mempunyai kekuatan hukum megikat. Harus dipahami bahwa menurut Pasal 24C ayat (1) UUD 1945 Putusan Mahkamah Konstitusi itu bersifat megikat, final and banding, tak dapat dilakukan upaya hukum lagi.

Putusan MK tersebut semakin memangkas kewenangan Komisi Yudisial. Eksistensi Undang-Undang Nomor 18 Tahun 2011 sebagai upaya memperkuat wewenang dan tugas Komisi Yudisial sebagai lembaga negara independen yang menjalankan fungsi checks and balances di bidang kekuasaan kehakiman dalam rangka mewujudkan kekuasaan kehakiman yang merdeka untuk menegakan hukum dan keadilan bagi seluruh rakyat Indonesia semakin sulit ditegakkan. Padahal, kehadiran Komisi Yudisial dalam UUD 1945 itu tidak terlepas dari adanya upaya untuk memperkuat kekuasaan kehakiman dalam struktur ketatanegaraan Indonesia. Urgensi untuk memperkuat kekuasaan kehakiman adalah sebagai konsekuensi logis dari dianutnya paham negara hukum (rechstaat) di Indonesia. ${ }^{18}$

Prinsip utama pengawasan oleh Komisi Yudisial bertujuan agar semua hakim dalam menjalankan wewenang dan tugasnya sungguh-sungguh didasarkan dan sesuai dengan peraturan perundang-undangan yang berlaku, kebenaran, dan rasa keadilan masyarakat serta menjunjung tinggi kode etik profesi hakim. Dengan demikian, keluhuran martabat, serta perilaku hakim. (Soekotjo Soeparto, 2009).

Adanya kehormatan dan keluhuran martabat kekuasaan kehakiman yang merdeka dan bersifat imparsial (independent and impartial judiciary) diharapkan dapat diwujudkan, yang sekaligus dapat diimbangi oleh prinsip akuntabilitas kekuasaan kehakiman, baik dari segi hukum maupun segi etika. Posisi Komisi Yudisial dalam menjaga dan menegakkan kehormatan hakim, perlu memperhatikan apakah putusan yang dibuat telah sesuai dengan kehormatan hakim dan rasa keadilan yang timbul dari masyarakat. Selanjutnya, demi keluhuran martabat hakim, Komisi Yudisial harus mengawasi apakah profesi hakim itu telah dijalankan sesuai etika profesi dan memperoleh pengakuan masyarakat. Tujuan lain pengawasan itu, menjaga agar para hakim tetap dalam hakikat kemanusiannya, berhati nurani, sekaligus memelihara harga dirinya, dengan tidak melakukan perbuatan tercela. Oleh karena itu, jika Komisi Yudisial tidak kuat dalam mengawal hal tersebut, bukan tak mustahil supremasi hukum di Indonesia tak lagi mengenal dan menerapkan prinsip keadilan. Komisi Yudisial diorientasikan untuk memastikan bahwa semua hakim sebagai pelaksana utama dari fungsi pengadilan itu berintegritas tinggi, jujur, dan

${ }^{18}$ Farid Wadji, Memperkuat Komisi Yudisial Dalam Menjaga Integritas Wakil Tuban, Cetakan Pertama, Setara Press, Malang, 2019, hlm. 23-24 
profesional, sehingga memperoleh kepercayaan dari masyarakat dan para pencari keadilan (Jawahir Thontowi, 2011).

Masalah lain yang perlu dituntaskan adalah tafsiran kewenangan pengawasan perilaku hakim (ranah kode etik) yang sering dibenturkan dengan terminologi teknis yudisial/yustisial (ranah teknis peradilan). Apalagi dalam berbagai kasus, Mahkamah Agung masih banyak memeriksa hakim padahal Komisi Yudisial sudah lebih dahulu memeriksa dugaan pelanggaran kode etik. Tanpa adanya penyamaan persepsi norma Pasal 20 ayat (3) UU Nomor 18 Tahun 2011, Pelaksanaannya tetap akan menjadi polemik yang tak berkesudahan. Rumusan hukum sduah jelas memberi kewenangan Komisi Yudisial untuk melakukan penyadapan. Bahkan aparap penegak hukum wajib menindaklanjuti (Pasal 20 ayat (4)).

Seperti dikatakan sebelumnya, bahwa dalam putusan Mahkamah Konstitusi Nomor 005/PUU-IV/2006 tersebut, Mahkamah Konstitusi menyatakan bahwa sepanjang menyangkut perluasan pengertian hakim menurut Pasal 24B ayat (1) Undang-Undang Dasar 1945 yang meliputi hakim konstitusi terbukti bertentangan dengan Undang-Undang Dasar 1945, sehingga permohonan para pemohon harus dikabulkan.

Putusan Mahkamah Konstitusi yang menyatakan bahwa hakim Mahkamah Konstitusi tidak termasuk yang diawasi oleh Komisi Yudisial, sesungguhnya tidak tepat karena hakim konstitusi juga hakim yang perlu diawasi perilakunya oleh lembaga pengawas eksternal supaya tidak terjadi disparitas pengawasan oleh Komisi Yudisial terhadap pelaku kekuasaan kehakiman.

Putusan Mahkamah Konstitusi atas Komisi Yudisial tersebut juga tidak dapat dipertanggung-jawabkan secara akademis. Hal itu bisa dilihat dari pernyataan Ketua Mahkamah Konstitusi itu sendiri yakni Jimly Asshiddiqie yang mengatakan bahwa: ${ }^{19}$

“Dari ketetentuan mengenai Komisi Yudisial ini dapat dipahami bahwa jabatan hakim dalam konsepsi UUD 1945 dewasa ini adalah jabatan kehormatan yang perlu dijaga dan ditegakkan kehormatannya oleh suatu lembaga yang juga bersifat mandiri, yaitu Komisi Yudisial. Pembentukan lembaga baru ini dapat dikatakan merupakan pengembangan Iebih lanjut ide pembentukan Majelis Kehormatan Hakim Agung yang sudah berkembang selama ini. Akan tetapi, jika majelis semacam ini dibentuk di Iingkungan internal Mahkamah Agung, maka sulit diharapkan akan efektif menjalankan fungsi pengawasan atas kehormatan hakim agung itu sendiri, karena kedudukannya yang tidak independen terhadap subjek yang akan diawasi.

19 Jimly Asshiddiqie, Kedudukan Mabkamah Konstitusi dalam Struktur Ketatanegaraan Indonesia, dalam Mabkamah Konstitusi, Bunga Rampai Mabkamah Konstitusi Republik. Indonesia, Setjen dan Kepaniteraan Mahkamah Konstitusi Republik Indonesia, Jakarta, 2005, hlm. 35 
Di samping itu, jika lembaga ini dibentuk di dalam struktur Mahkamah Agung, maka subjek yang diawasinya hanya terbatas pada hakim agung saja. Oleh karena itu, keberadaan lembaga Komisi Yudisial ini dibentuk tersendiri di luar Mahkamah Agung, sehingga subjek yang diawasinya dapat diperluas ke semua hakim, termasuk hakim konstitusi dan hakim di seluruh Indonesia".

M. Laica Marzuki juga menyatakan: “Konstitusi memberikan kewenangan kepada Komisi Yudisial guna menjaga dan menegakkan kehormatan, keluhuran martabat serta perilaku hakim... hal ini dimaksud berkaitan dengan kewenangan Komisi Yudisial melakukan pengawasan terhadap perilaku hakim... kewenangan pengawasan demikian juga berlaku terhadap perilaku hakim konstitusi ...". 20

Dalam risalah amandemen UUD 1945, tidak pernah disebutkan bahwa hakim konstitusi tidak termasuk dalam pengertian hakim. Artinya, dengan tidak dibahas dan disebutkan bahwa hakim konstitusi masuk dalam ranah pengawasan Komisi Yudisial tidak berarti bahwa hakim konstitusi dapat ditafsirkan tidak masuk dalam wilayah pengawasan Komisi Yudisial.

Menurut Jakob Tobing, selaku mantan Ketua PAH I BP MPR, yang ikut mempersiapkan materi amandemen UUD 1945. Menurut Jakob Tobing, ${ }^{21}$ "Semula Komisi Yudisial diusulkan untuk dibentuk di tiap tingkat peradilan, pengadilan negeri, pengadilan tinggi dan pengadilan kasasi. Anggota Komisi Yudisial adalah pakar hukum, tokoh praktisi hukum, dan tokoh masyarakat setempat untuk masa jabatan tertentu dengan tugas dan kewenangan untuk mengusulkan calon hakim sesuai tingkatannya dan menjadi badan kehormatan eksternal untuk mengawasi perilaku hakim, termasuk di tingkat nasional hakim agung dan hakim konstitusi, tanpa ada pengecualian... Komisi Yudisial akan mencermati perilaku para hakim guna mencegah terjadinya penyalahgunaan kemerdekan hakim. PAH I MPR akhirnya menyepakati Komisi Yudisial hanya dibentuk di tingkat nasional saja dengan tugas mengusulkan calon hakim agung (anggota Mahkamah Agung) kepada DPR. Tetapi semangat Komisi Yudisial tetap, yaitu untuk mengawasi para hakim semuanya termasuk hakim konstitusi dalam rangka menjaa dan menegakkan kehormatan, keluhuran martabat serta perilaku hakim sebagai bagian dari kekuasaan kehakiman yang merdeka..."

Pendapat senada juga disampaikan oleh Soetjipno yang sebagai mantan anggota PAH-I BP MPR 1999-2004 mengtakan, bahwa Komisi Yudisial, dalam

${ }^{20}$ M. Laica Marzuki, “Komisi Yudisial dan Relevansinya dengan Kekuasaan Kehakiman”, Jurnal Konstitusi, Vol. VI No. 2, 2006, hlm 86

21 Rofiqul Umam dkk (Editor), Membangun Jalan Demokrasi, Kesimpulan Pemikiran Jakob Tobing tentang Perubahan UUD 1945, (Jakarta: Konstitusi Press, 2008), hlm. 264. Lihat Juga Ni'matul Huda, Dinamika Ketatanegaraan Indonesia Dalam Putusan Mahkamah Konstitusi, UII Press, Yogyakarta, 2011, hlm. 67 
rangka check and balances ini, adalah untuk mengontrol perilaku para hakim dalam seluruh jajaran Mahkamah Agung dan Mahkamah Konstitusi demi menjaga martabat dan kehomatan hakim keseluruhannya. Oleh karena itu yang menjadi sasaran utama Komisi Yudisial adalah aspek adminidtratif personil hakim, yaitu para hakim dalam seluruh jajaran kekuasaan yudikatif, dan bukan aspek operasional kekuasaan yudikatif. ${ }^{22}$

Mengenai Putusan Mahkamah Konstitusi dalam kasus kewenangan Komisi Yudisial, para ahli hukum tata negara membuat suatu forum untuk melakukan eksaminasi putusan tersebut yang dinilai kontroversial, yaitu:23 pertama, putusan Mahkamah Konstitusi ini di luar harapan masyarakat karena menganulir pasalpasal strategis dalam upaya menciptakan peradilan yang bersih. Kedua, Mahkamah Konstitusi dinilai bertindak terlalu jauh melampaui kewenangannya ketika menganulir beberapa pasal yang terkait dengan wewenang pengawasan Komisi Yudisial. Ketiga, Putusan Mahkamah Konstitusi dalam kasus ini terkesan dipaksakan karena klausula-klausula yang dinilai oleh Mahkamah Konstitusi bertentangan dengan UUD 1945 sesungguhnya justru menjelaskan lebih detail ketentuan yang belum diatur secara jelas oleh pasal 24B UUD 1945. Keempat, Mahkamah Konstitusi punya kecenderungan menjadi lembaga yang hegemonik dan berpotensi mengancam keseimbangan konsep separation of powers dan prinsip checks and balances yang menjadi ide dasar munculnya Mahkamah Konstitusi dalam UUD 1945.

Menurut Ni'matul Huda, bahwa putusan Mahkamah Konstitusi yang menyatakan bahwa hakim Mahkamah Konstitusi tidak termasuk yang diawasi oleh Komisi Yudisial, sesungguhnya tidak tepat karena hakim konstitusi juga hakim yang perlu diawasi perilakunya oleh lembaga pengawas eksternal supaya tidak terjadi disparitas pengawasan oleh Komisi Yudisial terhadap pelaku kekuasaan kehakiman. Dengan putusan Mahkamah Konstitusi tersebut justru terjadi conflict of interest dalam diri Mahkamah Konstitusi. Potensi menyimpang dari Mahkamah Konstitusi pun sesusungguhnya perlu diawasi, supaya Mahkamah Konstitusi tidak tumbuh menjadi super body. ${ }^{24}$

Berdasarkan masalah di atas, dengan ketiadaan lembaga pengawas eksternal yang melakukan fungsi pengawasan terhadap etika dan perilaku hakim

22 Soetjipno, Komisi Yudisial dan Pengawasan Hakim, dalam Bunga Rampai Refleksi Satu Tabun Komisi Yudisial, Sekretariat Jenderal Komisi Yudisial Republik Indonesia, Jakarta, 2006, hlm. 398

23 Majelis Eksaminasi, Eksaminasi Putusan Mabkamah Konstitusi Nomor 005/PUU-IV/2006 Pengujian Undang-Undang Nomor 22 Tabun 2004 Tentang Komisi Yudisial Dan Undang-Undang Nomor 4 Tabun 2004 Tentang Kekuasaan Kehakiman, Diselenggarakan Oleh Pusat Kajian Anti Korupsi Dan Indonesian Court Monitoring, Yogyakarta 26-27 September 2006. Ibid., hlm. 79

${ }^{24}$ Ni'matul Huda, UUD 1945 dan Gagasan Amandemen Ulang, Rajawali Press, Jakarta, 2008, hlm. 276 dalam 
Mahkamah Konstitusi, sehingga menyebabkan terjadinya tirani kekuasaan dalam tubuh Mahkamah Konstitusi tersebut, yang dampaknya akan merusak wibawa Mahkamah Konstitusi itu sendiri. Dal hal itu terbukti dengan adanya kasus penangkapan seoarang ketua Mahkamah Konstitusi Akil Mochtar oleh KPK, karena tertangkap tangan sedang melakukan transaksi jual beli putusan.

\section{Urgensi Pengawasan Kekuasaan Kehakiman oleh Lembaga Eksernal (Komisi Yudisial)}

Sebagai komisi negara independen, Komisi Yudisial (KY) dijamin secara konstitusional melalui Pasal 24B UUD 1945. Secara teoritik, KY berkedudukan sebagai lembaga negara utama yang mempunyai fungsi supporting/auxiliary terhadap kekuasaan kehakiman. Secara konstitusional KY memiliki kewenangan mengusulkan pengangkatan hakim agung dan mempunyai wewenang lain dalam rangka menjaga dan menegakkan kehormatan, keluhuran martabat, serta perilaku hakim. Pengaturan lebih lanjut perihal kedudukan dan kewenangan KY diatur dengan Undang-Undang Nomor 18 Tahun 2011 tentang Perubahan Atas Undang-Undang Nomor 22 Tahun 2004 tentang Komisi Yudisial. ${ }^{25}$

Jika dianalisis dari kewenangan, terdapat dua kewenangan KY yang secara konstitusional diberikan oleh UUD. Pertama, mengusulkan pengangkatan calon hakim agung. Pasal 24A ayat (3) UUD 1945, telah menyatakan bahwa dalam hal pengangkatan calon hakim agung, terdapat tiga poros kekuasaan yang terlibat secara langsung (KY-DPR-Presiden) dalam proses pengangkatan hakim agung. Penjaringan dilakukan oleh KY kemudian dimintakan persetujuan oleh DPR (rigt to confirm) dan diserahkan kepada Presiden untuk ditetapkan sebagai hakim agung. Di satu sisi, keterlibatan KY sebagai komisi negara independent diperlukan untuk meminimalisir masuknya kepentingan politik dalam penjaringan calon hakim agung. Di sisi lain, keterlibatan DPR dan Presiden juga diperlukan sebagai bentuk akuntabilitas terhadap kinerja KY dalam menjaring calon hakim agung. Artinya secara konseptual keterlibatan masing-masing lembaga dapat dimaknai sebagai bentuk checks and balances terhadap proses pengangkatan hakim agung. ${ }^{26}$

Kedua, menjaga dan menegakkan kehormatan, keluhuran martabat, serta perilaku hakim. Pada titik ini, diperlukan kehati-hatian dalam memahami hubungan pengawasan antara KY dan perilaku hakim. Bahwa benar jika dikatakan subjek pengawasan KY diletakan kepada etika dan kehormatan perilaku hakim, dan bukan pada fungsi kelembagaan MA atau badan peradilan. Sebab, KY tidak mengawasi produk putusan yang dikeluarkan oleh badan peradilan. Namun, tidak tepat jika

${ }^{25}$ Idul Rishan, Hukum \& Politik Ketatanegaraan, Cetakan Pertama, FH UII PRESS, Yogyakarta, 2020, hlm. 205-206

${ }^{26}$ Ibid., 
lahir konklusi yang menyatakan KY tidak melaksanakan fungsi checks and balances dalam konteks pengawasan etika dan perilaku hakim. ${ }^{27}$

Kehadiran Komisi Yudisial di Indonesia didasarkan pemikiran bahwa hakim agung yang sudah duduk di Mahkamah Agung dan para hakim merupakan figurfigur yang sangat menentukan dalam perjuangan menegakkan hukum dan keadilan, ${ }^{28}$ apalagi hakim yang sudah duduk pada tingkat peradilan tertinggi dalam susunan peradilan. Sebagai negara hukum masalah kehormatan dan keluhuran martabat, serta perilaku seluruh hakim merupakan hal yang sangat strategis untuk mendukung upaya menegakkan peradilan yang handal dan realisasi paham dalam negara hukum. Melalui Komisi Yudisial ini, diharapkan dapat diwujudkan lembaga peradilan yang sesuai dengan harapan rakyat sekaligus dapat diwujudkan penegakan hukum dan pencapaian keadilan melalui putusan hakim yang terjaga kehormatan dan keluhuran martabat serta perilakunya.

Keberadaan Komisi Yudisial diharapkan hakim tidak lagi menyalahgunakan kekuasaannya dengan berlindung dibalik dalih kekuasaan yang merdeka dalam mengetukkan palunya. Eksistensi Komisi Yudisial dengan atribusi langsung dari Undang-Undang Dasar 1945 dan Undang-Undang Komisi Yudisial menjadi sangat penting dan strategis dalam menjaga hukum agar tidak disalahgunakan oleh hakim.

Komisi Yudisial sebagai institusi yang berwenang mengawasi tingkah laku hakim, pejabat dan pegawai peradilan memiliki fungsi yang sangat penting dalam memberantas mafia peradilan. Ketegasan dan konsistensi institusi ini, sangat jelas untuk menciptakan pemerintahan yang bersih dalam tubuh lembaga peradilan. Sikap ini sangat didambakan rakyat Indonesia mengingat penegakan keadilan semuanya bertumpuk pada tangan hakim. Komisi Yudisial mengawasi agar perilaku hakim menjadi baik (good conduct), sehingga dapat menjadi symbol mengenai pentingnya infra struktur sistem etika perilaku (good conduct) dalam sistem ketatanegaraan menurut UUD 1945..$^{29}$

Di antara berbagai cara menjaga martabat hakim sebagai aktor utama pengadilan adalah dirumuskannya prinsip-prinsip dan kode etik yang berlaku universal, seperti dimuat dalam Bangalore Principle ${ }^{30}$ yaitu hakim yang menjaga:

a. Independensi (independence);

b. Imparsialitas (imparciality);

\footnotetext{
${ }^{27}$ Ibid.,

28 A. Ahsin Thohari, "Dari Law Enforcement ke Justice Enforcement", Harian Kompas, 3 Juli, 2002.

${ }^{29}$ Ibid.,

30 Banglore Principles Of Judicial Conduct Adalab Prinsip-Prinsip Yang Disusun Oleh Para Hakim Dari Beberapa Negara Dunia Sebagai Standar Kode Etik Hakim. Prinsip-Prinsip Ini Didesain Untuk Memberikan Panduan Untuk Menyusun Kode Etik Para Hakim Di Seluruh Dunia. Nama Bangalore Merujuk Pada Sebuah Kota Di India Tempat Prinsip-Prinsip Ini Dirumuskan (MK-KY Sepakat Gunakan Banglore Principles Untuk Pedoman Kode Etik Melalui $\quad$ Http://Www.Hukumonline.Com/Berita/Baca/Hol13395/Mkky-Sepakat-Gunakan-IbanglorePrinciplesi-Untuk-Pedoman-Kode-Etik, Diakses 27 Agustus 2021).
} 
c. Integritas (integrity);

d. Kesopanan (propriety);

e. Persamaan (equality);

f. Kompetensi dan ketekunan (competence and diligence).

Enam prinsip yang dimuat dalam Bangalore Principle itu menjadi dasar dirumuskannya Kode Etik Profesi Hakim serta Kode Etik dan Pedoman Perilaku Hakim yang termuat dalam Surat Keputusan Bersama Mahkamah Agung dan Komisi Yudisial yang memuat 10 butir sebagaimana termuat dalam Peraturan Bersama No: 02/PB/MA/IX/2012 dan No 02/PB/P.KY/09/2012 Tentang Panduan Penegakan Kode Etik dan Pedoman Perilaku Hakim. Seluruh kualifikasi hakim yang dimuat dalam Banglore Principle yang kemudian diterjemahkan dan diperluas ke dalam 10 pedoman perilaku hakim itu adalah kewajiban kumulatif bukan alternatif bagi hakim, hak bagi setiap orang yang diadili serta hak bagi masyarakat luas.

Kekuasaan kehakiman yang merdeka (independency of judiciary) merupakan syarat mutlak (conditio sine qua non) tegaknya hukum dan keadilan dan harus mendapat jaminan konstitusional yang kuat dari negara. Tetapi harus diingat bahwa independensi itu bukanlah pemberian negara atau pemberian hukum. Independensi itu build in atau inherent dalam hati nurani dan akal sehat hakim seketika seseorang dinyatakan sebagai hakim. Negara datang kemudian untuk melegitimasi atau melegalisasi dan/atau (etika) agar memiliki kekuatan perlindungan hukum, dan dapat dipersoalkan secara hukum bila ada pelanggaran. ${ }^{31}$

Wilayah independensi hakim yang harus ia jaga mencakup etika dan perilaku di luar dan di dalam sidang. Di luar sidang, hakim harus menghindarkan diri dari perilaku tercela, citra negative, dan konfil kepentingan atau tindakan-tindakan yang potensial mendistorsi independensinya. Dalam cerita lama, hakim lebih baik basah kuyup diguyur hujan daripada menerima pinjaman paying dari siapapun, karena dikhawatirkan si pemberi paying berperkara di pengadilan. Selain itu, dalam persidangan, hakim wajib menjaga dan menjamin bahwa proses pemeriksaan, proses mengadili, dan menjatuhkan putusan bebas dari campur tangan siapapun.

Independensi adalah nyawa yang menggerakkan syaraf-syaraf keadilan hakim. Independensi juga merupakan paradigma, sikap, etos, dan etika sehingga keseluruhan totalitas fisik dan non-fisik hakim sebagai wakil Tuhan penegak keadilan di muka bumi memiliki legalitas moral, sosial, dan spiritual yang kuat.

${ }^{31}$ Farid Wajdi, Et. Al., Pengawasan Hakim Dan Penegakan Kode Etik Di Komisi Yudisial, Cetakan Pertama, Sinar Grafika, Jakarta, 2020, hlm. 185 
Pentingnya independensi peradilan dijamin oleh negara terlihat dalam penyataan Basic Principles on the Independence of the judiciary yang menegaskan bahwa independensi kekuasaan kehakiman (peradilan) harus ditetapkan dalam konstitusi atau undang-undang negara, dan menjadi tugas pemerintah serta lembaga-lembaga lainnya untuk menghormati dan menjaganya. ${ }^{32}$

Peradilan yang adil dan tidak memihak adalah roh negara hukum seperti negara Indonesia berdasarkan hukum sebagai panglima tertinggi. Prinsip-prinsip peradilan yang tidak memihak adalah norma HAM internasional yang dirancang untuk melindungi individu dari pembatasan yang tidak sah dan sewenangwenang atau perampasan atas hak-hak dasar dan kebebasaan warga negara. Peradilan yang adil dan tidak memihak adalah rangkaian proses peradilan dan Pra-Peradilan, dan Pasca-Peradilan. Dalam setiap tahap peradilan itu terdapat hak-hak para pencari keadilan yang wajib diberikan kepada tersangka, terdakwa, dan terpidana.

Keberadaan Komisi Yudisial di dalam struktur kekuasaan kehakiman suatu negara adalah untuk keluar dari latar belakang permasalahan kurang atau tidak berjalannya monitoring terhadap lembaga peradilan, tidak adanya lembaga penghubung antara kekuasaan kehakiman dan kekuasaan pemerintah, kekuasaan kehakiman terlalu disibukkan dengan persoalan-persoalan teknis non-hukum, buruknya kualitas dan konsistensi putusan, dan perekrutan hakim selalu dipolitisasi oleh lembaga-lembaga politik. Kehadiran Komisi Yudisial diidealkan akan mampu mengatasi persoalan-persoalan tersebut dengan cara melakukan monitoring secara intensif terhadap lembaga peradilan, menjadi perantara (mediator) antara lembaga peradilan dengan departemen kehakiman, meningkatkan efisiensi dan efektivitas lembaga peradilan dalam banyak aspek (karena tidak lagi disibukkan dengan hal-hal yang tidak berkaitan langsung dengan aspek hukum), menjaga kualitas dan konsistensi putusan lembaga peradilan, dan meminimalisasi terjadinya politisasi terhadap rekrutmen hakim. ${ }^{33}$

Dalam melaksanakan fungsi pengawasan terhadap perilaku hakim, sesuai dengan wewenang dan tugas dalam Pasal 13 huruf (b) dalam Undang-Undang Komisi Yudisial, Komisi Yudisial mempunyai wewenang dalam menegakkan kehormatan dan keluhuran marabat serta menjaga perilaku hakim..$^{34}$ Selanjutnya dalam Pasal 20 dijelaskan bahwa dalam melaksanakan wewenang sebagaimana

32 Ibid.

33 A. Ahsin Thohari, Komisi Yudisial \& Reformasi Peradilan, Cetakan Pertama, Elsam, Jakarta, 2004, hlm. 151

34 Secara Terminologi Hakim Yang Dimaksud Adalah Hakim Agung Dan Hakim Pada Badan Peradilan Disemua Lingkungan Yang Berada Dibawah MA Serta Hakim Mahkamah Konstitusi Sebagaimana Dimaksud Dalam UUD 1945. 
diaksud dalam Pasal 13 huruf b, Komisi Yudisial mempunyai tugas melakukan pengawasan terhadap perilaku hakim dalam rangka menegakkan kehorrmatan dan keluhuran martabat serta menjaga perilaku hakim.

Kewenangan pengawasan ini merupakan wujud dari pengawasan fungsional secara eksternal (control ekstern) terhadap perilaku hakim yang dilaksanakan secara mandiri dan objektif. Adanya kewenangan pengawasan Komisi Yudisial berdasar Pasal 13 huruf (b) merupakan fungsi penting dalam menunjang independensi peradilan dengan menguatkan kinerja pengawasan fungsional intern yang dilakukan oleh Mahkamah Agung dan Mahkamah Konstitusi. Dari aspek kemnafaatannya, wewenang dan tugas pengawasan tersebut diorientasikan untuk memastikan bahwa semua hakim sebagai pelaksana utama dari fungsi pengadilan itu berintegritas tinggi, jujur dan professional, sehingga memperoleh kepercayaan dari masyarakat dan pencari keadilan.

Apabila dikaji secara mendalam, objek pengawasan Komisi Yudisial mencakup hakim Mahkamah Agung, hakim peradilan dibawahnya dan hakim Mahkamah Konstitusi. Adanya fungsi pengawasan ini tentunya menjadi urgen karena pengawasan dilakukan secara eksternal, sistematis, dan intensif oleh lembaga independen terhadap badan peradilan dengan partisipasi masyarakat yang sebesar-besarnya. Konsekuensi logis dari kewenangan ini menjamin secara langsung hak-hak stakeholder dan para pencari keadilan dalam mewujudkan peradilan yang akuntabel sehingga dapat mewujudkan perilaku hakim yang bersih, berwibawa, dan merdeka. Adanya pengawasan ini karena pengawasan intern yang dilakukan Mahkamah Agung dan Mahkamah Konstitusi dianggap kurang optimal karena lemahnya implementasi pegawasan melekat atasan terhadap bawahannya di lingkungan Mahkamah Agung maupun Mahkamah Konstitusi.

Apabila dikaji secara mendalam, objek pengawasan Komisi Yudisial mencakup hakim Mahkamah Agung, hakim peradilan dibawahnya dan hakim Mahkamah Konstitusi. Adanya fungsi pengawasan ini tentunya menjadi urgen karena pengawasan dilakukan secara eksternal, sistematis, dan intensif oleh lembaga independen terhadap badan peradilan dengan partisipasi masyarakat yang sebesar-besarnya. Konsekuensi logis dari kewenangan ini menjamin secara langsung hak-hak stakeholder dan para pencari keadilan dalam mewujudkan peradilan yang akuntabel sehingga dapat mewujudkan perilaku hakim yang bersih, berwibawa, dan merdeka. Adanya pengawasan ini karena pengawasan intern yang dilakukan Mahkamah Agung dan Mahkamah Konstitusi dianggap kurang optimal karena lemahnya implementasi pegawasan melekat atasan 
terhadap bawahannya di lingkungan Mahkamah Agung maupun Mahkamah Konstitusi.

Pembatalan wewenang Komisi Yudisial dalam mengawasi hakim Mahkamah Konstitusi terdapat dalam Putusan Nomor 005/PUU-IV/2006, putusan tersebut adalah Putusan Mahkmah Konstitusi terhadap permohonan pengujian Undang-Undang Nomor 22 Tahun 2004 tentang Komisi Yudisial dan Undang- Undang Nomor 4 Tahun 2004 tentang Kekuasaan Kehakiman terhadap Undang-Undang Dasar 1945. Para pemohon 31 Hakim Agung yang menganggap hak konstitusionalnya dirugikan oleh ketentuan-ketentuan udang-undang Komisi Yudisial dan undang-undang Kekuasaan Kehakiman.

Padahal saat ini kita membutuhkan lembaga eksernal Komisi Yudisial untuk melakukan pengawasan terhadap kekuasaan kehakiman baik itu hakim di Mahkamah Agung dan Mahkamah Konstitusi serta hakim-hakim yang berada dibawah MA, sehingga urgensi untuk memperkuat kewenangan Komisi Yudisial dalam pengawasan hakim secara eksternal.

\section{Penutup}

Berdasarkan hasil penelitian dan pembahasan yang telah diuraikan di atas maka dapat disimpulkan sebagai berikut: pertama, Putusan Mahkamah Konstitusi Nomor 005/PUU-IV/2006 yang menyatakan bahwa pasal-pasal pengawasan Komisi Yudisial bertentangan dengan UUD 1945 dan tidak mempunyai kekuatan hukum megikat. Putusan Mahkamah Konstitusi ini telah memperlemah kewenangan Komisi Yudisial dalam pengawasan secara eksternal lembaga kekuasaan kehakiman di Indonesia. Kedua, Putusan Mahkamah Konstitusi yang menyatakan bahwa hakim Mahkamah Konstitusi tidak termasuk yang diawasi oleh Komisi Yudisial, sesungguhnya tidak tepat karena hakim konstitusi juga hakim yang perlu diawasi perilakunya oleh lembaga pengawas eksternal supaya tidak terjadi disparitas pengawasan oleh Komisi Yudisial terhadap pelaku kekuasaan kehakiman. Ketiga, Adanya urgensi untuk pengawasan satu atap oleh Komisi Yudisial terhadap kekuasaan kehakiman baik itu hakim di Mahkamah Agung dan Mahkamah Konstitusi serta hakim-hakim yang berada dibawah MA.

\section{Daftar Pustaka}

\section{Buku}

Asshiddiqie, Jimly, Kedudukan Mahkamah Konstitusi dalam Struktur Ketatanegaraan Indonesia, dalam Mahkamah Konstitusi, Bunga Rampai Mahkamah Konstitusi Republik Indonesia, Setjen dan Kepaniteraan Mahkamah Konstitusi Republik Indonesia, Jakarta, 2005. 
Huda, N'imatul, Dinamika Ketatanegaraan Indonesia Dalam Putusan Mahkamah Konstitusi, UII Press, Yogyakarta, 2011. UUD 1945 dan Gagasan Amandemen Ulang, Rajawali Press, Jakarta, 2008.

Indrayana, Denny, Negeri Para Mafioso: Hukum disarang koruptor, Sinar Grafika, Jakarta, 2008.

Majelis Eksaminasi, Eksaminasi Putusan Mahkamah Konstitusi Nomor 005/PUUIV/2006 Pengujian Undang-Undang Nomor 22 Tahun 2004 Tentang Komisi Yudisial Dan Undang-Undang Nomor 4 Tahun 2004 Tentang Kekuasaan Kehakiman, Diselenggarakan Oleh Pusat Kajian Anti Korupsi Dan Indonesian Court Monitoring, Yogyakarta 26-27 September 2006.

Marzuki, Mahmud, Peter, Penelitian Hukum, Prenada Media, Jakarta, 2011.

Rishan, Idul, Hukum \& Politik Ketatanegaraan, Cetakan Pertama FH UII PRESS, Yogyakarta, 2020.

, Kebijakan Reformasi Peradilan, Cetakan Pertama FH UII PRESS, Yogyakarta, 2019.

Soetjipno, Komisi Yudisial dan Pengawasan Hakim, dalam Bunga Rampai Refleksi Satu Tahun Komisi Yudisial, Sekretariat Jenderal Komisi Yudisial Republik Indonesia, Jakarta, 2006.

Thohari, A. Ahsin, Komisi Yudisial \& Reformasi Peradilan, Cetakan Pertama Elsam, Jakarta, 2004.

Umam, Rofiqul dkk (Editor), Membangun Jalan Demokrasi, Kesimpulan Pemikiran Jakob Tobing tentang Perubahan UUD 1945, Konstitusi Press, Jakarta, 2008.

Wadji, Farid, Memperkuat Komisi Yudisial Dalam Menjaga Integritas Wakil Tuhan, Cetakan Pertama Setara Press, Malang, 2019.

Wajdi, Farid, Et. Al., Pengawasan Hakim Dan Penegakan Kode Etik Di Komisi Yudisial, Cetakan Pertama Sinar Grafika, Jakarta, 2020.

\section{Jurnal}

M. Laica Marzuki, "Komisi Yudisial dan Relevansinya dengan Kekuasaan Kehakiman", Jurnal Konstitusi , Vol. VI No. 2, 2006.

\section{Online}

Http://Www.Hukumonline.Com/Berita/Baca/Hol13395/Mkky-SepakatGunakan-Ibanglore-Principlesi-Untuk-Pedoman-Kode-Etik, Akses Agustus 2021.

\section{Artikel \& Media Cetak}

A. Ahsin Thohari, Dari Law Enforcement ke Justice Enforcement, Harian Kompas, 3 Juli, 2002.

Republika. co.id., Januari 2016, "Memperkuat Komisi Yudisial", Diaksed pada 27 Agustus 2021.

Saldi Isra, Opini Kompas “Kekuasaan Dan Perilaku Korupsi” 2009.

\section{Peraturan Perundang-Undangan}

Undang-Undang Dasar Negara Republik Indonesia Tahun 1945 
Undang-Undang Nomor 18 Tahun 2011 Perubahan Atas Undang-Undang Nomor 22 Tahun 2004 tentang Komisi Yudisial

\section{Putusan Pengadilan}

Putusan MK Nomor 005/PUU-IV / 2006. 